\title{
Humeyni Dönemi İran Dış Politikası (1979-1989)
}

\author{
Bekir HALHALL $\dot{I}^{1}$
}

Özet: Bu makalenin ana amac1, Şubat 1979 Devrimi sonucunda kurulan İran İslam Cumhuriyetinden Humeyni’nin ölümüne kadar olan dönemde Dış Politikaya Velayet-i Fakih teorisinin yansımasıdır. İran Dış Politikasını kapsamlı bir değerlendirmeye tabi tutmak için, genel siyasi/ uluslararası ilişkiler teorilerden ziyade İran'daki dini kurumları, doktrinleri, Şiiliğin karakteristik özellikleri ile protest yapısını bilmek gerekmektedir. Bu çalışmada, İran Dış Politikasını tamamen anlayabilmek için geleneksel-Batı merkezli olan uluslararası ilişkiler teorilerinin (Realizm, Liberalizm, Marksizm, Konstrüktivizm vb.) ötesine bakılması bir zorunluluk olarak karşımızda durmaktadır. Çalışmanın ilk kısımlarda, İran Dış Politikasında etkili olan unsurlar ve dış politikada İran İslam Devriminin etkileri ve liderler, ana hatlarıyla ele alınmakta, farklı yönleri açıklanmakta ve başarıları değerlendirilmektedir. Sonrasında ise, İran İslam Cumhuriyeti’nin Ortadoğu'daki ülkelere ve Amerikan Birleşik Devletleri’ne yönelik politikaları tartışılmaktadır.

Anahtar Kelimeler: İran, Dış Politika, Velayet-i Fakih, Ortadoğu, Devrim, Humeyni. 


\section{Giriş}

İran İslam Cumhuriyeti’nin zaferi ile birlikte İran Dış Politikası Ayetullah Humeyni’nin "İslam patentli” Şii teorileri ve düşünceleriyle şekillenmiştir. Teorisyen, karizmatik lider ve Şii İslam sisteminin kurucusu kabul edilen Humeyni tüm siyasi partileri, aktivistleri, devletin kurumları ve toplumun hemen hemen her kesimini kendine resmi anlamda itaat ettirmiş (Üstün 1999: 28-30), başlıca ulusal ve uluslararası politikaları da ona göre tanımlamış ve belirlemiştir.

İran İslam Cumhuriyeti yedinci asırda İslam devletinin ve peygamberinin (Hz. Muhammed) izinden giderek model olduğunu iddia etmektedir. Temelde Kuran ve ayetleri, özelde ise Şiilik olgusu İslam devrimine yeni anlamlar kazandırmıştır. Ancak, İslam Cumhuriyetinin Velayet-i Fakih doktrinin ${ }^{2}$ dini yetkisini temel alırken modern dönemin kurumlarını, toplumunu ve ekonomik boyutlarını kabul görmemektedir. Bu yüzden 1979 Devrimi çeşitli ekonomik, toplumsal ve ideolojik kaynak ve amaçlardan doğan ulusal bir kurtuluş hareketi olarak bilinmektedir (Onat 2013: 228). Fakih, dış politika kararlarının (Humeyni başat güç olmanın avantajını da kullanarak) yapılmasında önemli rolü olan bir şahıstır. Humeyni’n önderliğinde dünyanın en eski monarşilerinin birinin yıkılmasının ardından Velayet-i Fakih teorisi Şia geleneğinin tarihsel bir boşluğunu tamamlama sürecinde, Fakih' in pozisyon ve siyasetteki katkısını karar verici merci olarak aksettirmiştir. Bunun dışında, İslam devriminin zaferi İslam’nn bölgede sabit ve kalıcı bir düzlemi olduğuna; hatta uluslararası düzeyde de zamana ve modernleşmeye göre toplumdan topluma farklı bir düzlemi olduğunu göstermiştir. Bu zafer dünyada İslami düşüncenin canlanmasına ve entelektüel zeminde pekişmesine yol açmıştır. İslam devrimi Müslümanlara yeni bir bakış açısı kazandırmıştır. Böyle olunca da, devrimden itibaren İran bölge

2 Fakihin Vesayeti. Humeyni’nin dinsel meşruiyet (Tanrının egemenliği) ve siyasal meşruiyet (halkın iradesi) kombinasyonundan oluşan görüşlerinin temelini, kendisinin geliştirdiği Velayet-i Fakih doktrinidir. Bir başka deyişle, Ayetullah Humeyni bu teoriyi dinin ve siyasetin merkezine yerleştirerek ona siyaset üstü hakkaniyet kazandırmıştır. Günümüze kadar devam eden İran siyasetinin çekirdeği sayılan Velayet-i Fakih Kurumu, Humeyni tarafından yeniden yorumlanmış Şiiliğin en bariz örneğidir. 
politikası yeni rejimin önderleriyle ulusal gelişmeler ışı̆̆ında bir dereceye kadar kuvvetler dengesinin yapımını, İran seçkinleri gibi faktörler belirlemiştir. Bu dönemde dini liderler kademeli tahkimat eşliğinde güç ve statükoya karşı bir itiraz olarak bölgedeki baskıcı devletlere ve büyük güçlere karşı bir duruş sergilemişlerdir. Humeyni, özellikle geri kalmış Orta Doğu ülkelerini asıl nedeni gerçek İslami yönetimlerinin-kurallarının olmaması ve emperyalist devletlerin -İngiltere, $A B D$ ve Sovyetler Birliği- üçüncü ülkeleri sömürdüğünü çoğu defa ifade etmiştir. Hatta devrim öncesinde, bu emperyalist devletlerin kukla hükümetleri ve yerel işbirlikçileri başlica İran (Şah dönemi), Irak, Suudi Arabistan ve M1sır devletleri olduğunu açık açık ifade etmiştir.

İran şahının devrilmesiyle 1979 İslam Devrimi, İslami koalisyon, liberal, Marksist ve radikal güçlerin yardımıyla hem uluslararası arenada hem pro-aktif (ileriye dönük) Şii temelli dini akımlara hem de bloklar dışı (ne Doğu ne de Batı, sadece İslam) tanınmaya başlandı. Dini olarak, hiç bir ülke İran İslam Devriminin ulusal güvenliği sağlayamad1ğını söyleyemez. Şiiliğin karakteristik özellikleri ve protest dinamikler olayı anlamamızı sağlayacak en önemli faktörlerin başında gelir. İran Dış Politikasını kavramak için ayrıca Humeyni’nin konuşmaları ve diğer dini liderlerin inanç sisteminin bilinmesi gerekir. İslam Cumhuriyetinin inşa döneminde soğuk savaşın koşullarının hâkim olduğunu ve dünyanın Doğu ve Batı bloklar arasında bölündüğünü görebilmekteyiz. Bu ayrışma/bölünme aynı zamanda Ortadoğu ülkelerini ve bölgedeki bazı devletlerin iki blok arasında ulusal çıkar, güvenlik sorunsalı ve yönetim şeklinin sürdürülmesi-statüko gibi sebeplerden ötürü bir tercihte bulunmasını zorunlu kılmıştır. İran Şahı bu tercihini ABD’nin onun konumunu sağlamlaştırma çabalarıyla Batı yanlısı kapitalist blokta yapmıştı. İslam Devriminin zaferi ile İran artık ne Marksist blok ne de Kapitalist blokta yer alacaktı. Şii İslam olgusunu bir ideolojik devrim olarak kullanmış, her iki bloğu ve düşüncelerini rahatsız etmiş; üstelik Ortadoğu'nun kalbinde ekonomik ve siyasi açıdan geri kalmış üçüncü dünya ülkeleri olan Müslüman ülkelerini de rahatsız etmiştir. Bu dönemde Şiilik olgusu ve radikal hareketlerin İslami Dış Politika odaklı olmasıyla bölgenin güç dengesi değişmiştir; Batı ve Doğu blokları ve 
blokların dost ülkeleri başkalaşmıştır. 1979 İslam devriminden sonra İran'ın bölge ülkeleriyle ilişkilerinde, bilhassa Arap ülkeleriyle, çok önemli değişim ve dönüşümüne şahit olduk. Ulemalar ve devlet yöneticileri Arap ve Müslüman toplumlarının çoğunda İslami ayaklanmaların gerçekleştirilmesinde İran'dakine benzer bir devrimin olması taraftarlarıdır (Efegil,2012:58). Bu nedenle, İran İslam Cumhuriyetin Dış politikası kendine mahsustur; Kuran, Velayet-i Fakih Doktrini ve İslam Devrimi liderlerinin farklı bakış açılarında kök salmıştır. İran Dış Politikasını çalışmak yaygın hale getirilen siyasi teorilerden ziyade dini kurumların ilişkisini ve doktrinlerini bilmeyi gerektirmektedir. Bu çalışmada İran Dış Politikasını tamamen anlayabilmek için geleneksel-Batı merkezli olan uluslararası ilişkiler teorilerin (Realizm, Liberalizm, Marksizm, Konstrüktivizm vb.) ötesine bakmamız gerektiği tartışılmaktadır. Bu çalışmanın amaçlarından biri de, soğuk savaş döneminde Ortadoğu'daki bölünme ve değişimlerin İran İslam Cumhuriyetinin etkisiyle nasıl şekillendiğidir. Dolayısıyla, İran Dış Politikası ideoloji ve inanç sistemi açısından gözden geçirilmesi gerek iç gerekse de diş siyasette dini kavrayış ve ilkeleri odaklanmayı gerektirecektir.

\section{1. İran Dış Politikasında Etkili Unsurlar}

İran İslam Cumhuriyetinin Dış Politikasını şekillendiren iki temel unsur-Devrimcilik ve İslamcılık- değişimin ilk on yılının çekirdeğini oluşturmakla beraber ulus-devlet/milli çıkar anlayışının önüne geçmiş ve evrensel vatan-İslamcı enternasyonalizm- anlayışını kapsamıştır.

İslam Devriminin ardından diğer bölgedeki ülkelerle karşı karşıya gelme veya karşılıklı cepheleşme İran-Irak savaşının ilk sekiz yılına kadar devam etti. Görünürdeki İslam Cumhuriyeti özelliklerine dâhil devrimci fikirlerin hızla yayılması, Filistin ve Lübnan hareketleriyle liberal ve siyasi İslam’ın başkaldırısı Amerika’nın Ortadoğu'daki mevcudiyeti, bölgede statükodan beslenen Arap muhafazakâr yönetimlerini ve İsrail'in stratejik çıkarlarını tehlikeye sokmuştur. "Ezilen-ezen”, "sömürülen-sömüren”, "proletarya-burjuva”, "köle-efendi” gibi çelişkiler İslam Devriminin gerçekleşmesinin hemen ardından "mustazaf-müstekbir" 
ayrım ilişkisine dönüşmüş; ABD-İsrail-Batı Avrupa-Sovyetler Birliği ile İslam dünyasının yöneticileri müstek saflarında, İran ile birlikte Müslüman olsun olmasın fakir haklarının ise mustazaf saflarında konumlandırmıştır (Gündoğan 2011: 94).

Devrimin ilk dönemlerinde, yirminci yüzyılın en tehlikeli radikal gruplarının kol gezdiği, güvensizliğin hızla artığı bir dönemde, Humeyni dış politikasında İran'ın üstlendiği en önemli görev rejimin ihracı ve sömürülen ülkelerin destekçilerine karşı bir konum edinmiştir. İran İslam Cumhuriyeti’nin dış politikasını belirleyen en önemli etken devrim ideolojisidir. ${ }^{3}$ Ortadoğu' da örseleyici bir aktör olarak görülmesine rağmen, İran İslam Cumhuriyeti yönetimi başındaki Humeyni, sık sık Arap muhafazakâr hükümetlerini düşman olarak görmüş ve kendi kullandığı devrim avantajlarını empoze ederek baskıcı rejimlere karşı radikal İslami gruplara arka çımıştır. Kendisi ve kurumsallaştırdığ 1 diş politikaya göre, İsrail ile uzlaşmak için ortaya konacak her türlü çaba İslam Dünyasına ve Filistin'e ihanettir (Friedman 2010; Muran \& Atay 2009: 155-168; Watt 1997). Örneğin, Ayetullah Humeyni Ürdün Kralı Hüseyin, Fas Kralı Hasan ve Mısır Devlet Başkanı Mübarek’i ABD ve İsrail uşaklığıyla; Suudi Arabistan yöneticilerini Kâbe'nin bekçileri ve Müslümanların oradaki kötü temsilcileri olarak itham etmiştir (Backlash 2001: 248). Dolayısıyla, Humeyni devrim ideolojisi ile devrimin bölgede yayılımı ve değişimi için bölge hükümetlerine meydan okumuştur. İran İslam Cumhuriyetinin başta bölge halkları olmak üzere diğer halklar için de iyi bir örnek olabileceğini vurgulamıştır. İslam Cumhuriyeti Anayasasının (Hatemi: 1980: 63-64) giriş bölümündeki önemli maddeler arasında yer alan "dış siyaseti; İslami ölçüler ve tüm Müslümanlarla kardeşlik taahhütlerine bağlllık ve dünyanın bütün mustazaflarını himaye temelleri üzerine tanzim etmek" olduğu ifade edilmektedir. Yine diğer önemli maddelerden biri "sömürüyü tamamen yok

3 Bu ideoloji devrimin lideri Ayetullah Humeyni tarafından formüle edilmiştir. Bu ideolojinin diş politikaya yansıyan temel özellikleri arasında, müstekbir-mustazaf ayırımı, monarşi, ABD, İsrail, kapitalizm ve sosyalizm karşıtlı̆̆ı bulunmaktadır. Bundan daha önemlisi, İran yöneticilerine göre, beşeri devletlerin karşısında ilahi bir güç vardır ve değerler dizisinde millet ve millet kimliliğin bir anlamı yoktur. 
ederek yabancıların sömürge ve nüfuz girişimlerini önlemek” olduğunun altı çizilmiştir. Bu anayasa maddeleri göz önüne alındığında bariz bir şekilde İran İslam Cumhuriyetinin kapsamlı iç politikalarının İslami ve sömürüye karşı esaslar üzerine olan ilkeleri aynı zamanda dış politikayı da belirlemiştir. Buna ilaveten, Humeyni’nin görüşlerinin ve buna paralel olan İslam Cumhuriyeti Anayasasının, İslam’ı İranlılar için değil, diğer milletlerinin gereklerinin yerine getirmesini de kapsadığı görülmektedir.

Ulema ve devrimcilerin gözünde liberal hareketlere arka çıkmak, açıkça diğer ülkelere devrimin yayılmasını sağlama anlamı taşımaktadır. İran Anayasasının 154. Maddesinde (Hatemi: 1980: 63-64) yer alan ifadeler bunu doğrulamaktadır: "İran İslam Cumhuriyeti tüm insanların mutluluk müjdecisidir. Bağımsızlık, özgürlük, adalet ve hakkın egemenliğini, tüm insanların doğal hakkı olarak kabul etmektedir. Dolayısıyla diğer ülkelerin iç işlerine karışmaksızın, ezilenlerin ezenlere karşı haklı savaşını, dünyanın neresinde olursa olsun destekleyecektir." Devrimci İslam İdeolojisinin dış siyasette gördüğü temel ilkeler şu şekilde sıralanabilir: Evrensel bir İslam yönetiminin kurulmasına çalışmak, ezenler karşısında ezilenleri desteklemek- mustazaf- müstekbir ayrımı, ABD ve diğer büyük güçlerin İran'ı kullanmasını engelleme, Müslümanların haklarını savunmak ve İran İslam Devriminin ihracı. ${ }^{4}$

Unutulmaması gereken bir başka husus, İran-Irak savaşının yıllarca sürmesi ve devrimin savaş üzerinden bir dış politika belirlemesidir. İslam Cumhuriyeti bunu bir silah olarak başta Arap ülkeleri ve diğer bölgelerine karşı kullanmaya niyetlenmiştir. Böylece Saddam Hüseyin'e gelecek olası destek engellenmiş olmuştur. İran İslam Cumhuriyetinin evrensel bir İslam cumhuriyetini kurmak istemi ve rejim ihracı bölgede yalnızlaşmasına rağmen İran Anayasası Dış Politikasında ABD olmak üzere sömürgeci olarak tanımladığı süper güçlerle ve bölgedeki en önemli müttefiki İsrail'in gücünü de zayıflatmayı başarmıştır. Bölge insanları için bu, sadece devrim ihracı olarak okunmamış, ayrıca

4 Bundandır ki, İran’ı devrime taşıyan faktörlerin temeli etnisite ve ulustan ziyade dinin temel değer ve kültürü olduğu görülebilir. 
radikal devrimin inancı kendi despot rejimlerine karşı uygulayabilme imkânı ve umudu doğurmuştur. Devrimden kısa bir süre sonra, İran Şii grupları desteklemeye ve finanse etmeye başlamış, rehberliğini sağlayarak Bahreyn, Suudi Arabistan, Afganistan, Irak, Pakistan ve Lübnan gibi Şii popülasyona sahip ülkelerde rejim karşıtı ayaklanmalarında ve kendi ülkelerinde "gerçek İslam”a ulaşmalarında büyük rol oynamıştır (Rakel 2007: 160-164). Beyrut’taki ABD Elçiliğindeki patlamada İslami Cihat gruplarının sorumlu tutulması, Ekim 1983'de Lübnan'da $A B D$ ve Fransız Askeri üslerine karşı bombalı eylemler meydana gelmesi, Lübnan'daki Amerikan, İngiliz, Alman ve Fransız rehinelerin bir kriz olarak büyümesi, İran'da Humeyni’nin izinde yürüyen üniversite öğrencilerin Amerikan Büyükelçiliğini basarak planlarını ve casusluk dosyalarını gözler önüne sermesi gibi olaylar İslam Cumhuriyeti tarafından Batı'ya karşı düzenlenmiş eylemler birleşimidir. Sonuç olarak, $A B D$ ve diğer dost müttefik ülkeler Saddam Hüseyin için desteklerini geri çekmiştir. İran İslam Cumhuriyetini küresel anlamda toplumdan izole etme girişimlerine karşın ABD, İran’ kullanma sürecinin sona erdiğini anlamıştır. 1980'lerin sonlarına doğru, İran-Irak savaşının sona ermesi, İran'da daha pragmatist liderlerin işbaşına gelmesi, petrol politikasının artan önemi, Kuveyt'in Irak tarafından işgali ve İran’ın Soğuk Savaş sonrası dönemde bölge devletleriyle ilişkilerini yeniden geliştirme arzusu gibi nedenlerden ötürü İranlı yöneticiler, dış politika anlayışlarında değişikliğe gitmek zorunda kalmıştır (Efegil 2012: 58) .

Genel olarak 1979 İran Devrimini analiz eden birçok araştırmacı jeopolitik konum, siyasi kültür, toplumsal değerler, tarihsel tecrübeler, heterojen etnik yapı, Şii İslam anlayışı ve Şii İslam öğretisi, çarpık/eşitliksiz gelişme, sosyal yapı, ekonomi ve petrol gelirleri, gibi unsurların İran'ın Dış Politika yapım sürecini etkileyen önemli unsurlar olduğunu belirtmiştir (Efegil, 2012: 58). Öte yandan, Devrimin ilk ylllarından itibaren birbirlerinin yanı başında varlıklarını hissettiren pragmatistler ve radikaller, Humeyni sonrası 1lımlılar/reformistler ile radikal muhafazakârlar arasındaki iç çekişmeler dış siyaset ve güvenlik politikaları konularında kendini göstermiştir. Dış Politika karar verme sürecinde ise dini liderlik-Ayetullah Humeyni’nin karizmatik liderliği, anayasal kurumlar 
ve aktörler arasında gayri-resmi kişileşmiş ilişkiler gibi faktörler diş politikanın davranışlarını uzun süre belirleyebilmiştir.

\section{Dış Politikada İran İslam Devriminin Etkileri ve Liderler}

İslam Devriminin ardından Ayetullah Humeyni İran'ı duygusal ve dini dalgalara neden olabilecek bir baskıcı hükümete karşı, halkı güçlendirilmiş bir dini hükümet oluşturmayı hedeflemiştir. ${ }^{5}$ Humeyni’nin İran'daki devrimin önemli isimlerinden Mehdi Bezirgân'ı yeni hükümete atamasıyla İran-ABD beraberliğine son noktayı koymuş ve dış politikada kabine kararlarını daha çok "eşitlik" prensibi üzerine kurmuştur. ${ }^{6}$ Geçici hükümetin ardından iktidarın daha iyi güçlenerek dış politikasını devrimci-ideolojik bir eksene kaydıracağı görülecektir. ${ }^{7} \mathrm{Hu}-$

5 Humeyni’nin ağırlıklı konumuna rağmen, 1979 İran Devriminin gerçekleşmesinde çok önemli rol oynayan düşünür Dr. Ali Şeriati (1933-77) kabul edilmektedir.

6 Bununla beraber, Şiiliğe dayalı teokratik yapıda ve kilit kurumların Şii din adamların elinde olması nedeniyle İran nüfusunu oluşturan \%10’luk Sünni Kürt, Beluci ve Türkmenler ötekileştirilmiş ve üst düzey görevlerde yer alması engellenmiştir. Daha fazla bilgi için bkz, Arif Keskin, "Şii Jeopolitiği ve İran”, (der) Mehmet Tuncel, Ortadoğu’da Güç Savaşları: Hedef Neden İran? İstanbul: Etkileşim Yayınları, 2008, s. 55.

7 Devrimden sonra Mehdi Bezirgân yönetiminde atanan "Geçici Kabine"nin "liberal” bir yapısı vardı ve anayasa tamamlanıp 1980 yılının Ocak ayında Cumhurbaşkanlığı seçimleri yapılıncaya dek Humeyni’nin atadığı ve din adamlarından oluşan "Devrim Konseyi" varlığına devam etti. Nitekim bir süre sonra "liberal Kabine" ve "radikal" Devrim Konseyi arasında gerginlikler ortaya çıkmıştır. Geçiş döneminde Humeyni ve Kabine, İran'ın bağlantısız ve tarafsız bir politika izlemesi gerektiği konusunda hemfikirlerken, bağlantısızlık anlayışları farklıydı. Humeyni bu kavramı yalnızca süper güçlere bağımlılığı sona erdirmeyi değil, aynı zamanda onlarla ilişkilerde İran’ın belirleyici olması gerektiği şeklinde anlıyorken; Kabine, İran'ın kazançlı çıkacağı şekilde ABD ve SSCB ile ilişkilerin devamını amaçlamıştı. Diğer taraftan Kabine, bazı Ayetullahların başını çektiği, İran dışındaki Müslümanlara duyulan özel ilgiden rahatsızdi; bu hareketin diğer Müslüman devletlerle ilişkileri kötüleştirmesinden endişe ediyordu. Mesela, Dışişleri Bakanı İbrahim Yezidi devrimi "İran halkının özel bir ürünüdür” şeklinde tanımlarken, devrim ihracı fikrini onaylamıyordu. Ayrıca, büyükelçilerin Dışişleri Bakanlığı'nı atlayarak doğrudan Devrim Konseyi’nden aldıkları talimatlarla hareket etmesi Kabine'nin rahatsızlığını artırıyordu. Bu arada, zaman zaman Humeyni'nin inisiyatifiyle Komünist Tudeh Partisi'ne baskı yapılması ve ABD Büyükelçiliğiinin işgali gibi İran'ı diş politikada güç duruma düşürecek hadiseler cereyan ediyordu. Nitekim bu öyle bir boyuta varacaktır ki, Dışişleri Bakanı Yezidi görevini "Humeyni ve diğer ulemanın saldırgan ifadelerini yumuşatmak" olarak görecektir. Zira Humeyni’nin sözleri iç politikada olduğu gibi dış ilişkilerde 
meyni’nin öngördüğü diş politika ve büyük güçlere yönelik politikalar Muhammed Mussadık'a ${ }^{8}$ ait olan politikalarla aynıydı. Mussadık'in politikalarıyla paralel olmayan faaliyetler genelde olumsuz/eksik denge olarak görülmüş ki o günkü amaçlanan İngiltere-ABD’den bağımsız hareket etme bu dönemde ABD’nin tesirinden kurtulmak olarak görülebilir. İslam Devriminin hemen ardından bağımsız İran’nn Dış politikasını "tarih, İran’ın jeopolitik durumu, dini ülküler ve diğer ülkelerle göze göz dişe diş-kısasa kısas (quid pro quo)” diye bilinen diplomatik ilişkilere dayalı prensipler olarak ifade edilebilir.

Ancak, daha sonra içeride otarşik ekonomik yapı ve yönetimin merkezine Şii din adamlarını oturtan bir siyasal yapı (velayet-i fakih) aynı zamanda dış politika eksenini de belirlemiştir. Bununla beraber, $\mathrm{Hu}-$ meyni, önceliği İslam’a dayalı milli bir hükümete ve dış politikaya vermiştir. 04.11.1979 tarihinde ABD Elçiliğine saldırı ve sonrasında 444 gün süren rehine krizi İran Dış Politikasının diğer ülkelere yönelik "idealist devrim’in” daha ön plana çıkmasını sağlamıştır. Bu politikayla İran Uluslararası düzende kendi bağımsızlığını muhafaza etmeye çalışmıştır. Ancak, bu yeni “idealist" ve "devrimci” politikalar İran’i bilinen diplomatik ilişkilerden uzaklaştırmıştır. Rehine krizi sırasında Humeyni’nin temel endişesi Velayet-i Fakih teorisinin gelişmesinin önlenmesiydi. Bezirgân'ın 1979'daki istifası İran Dış Politikasını ve İslam Cumhuriyeti önünde engel gibi görülmeye başlansa da daha önce Dış İşleri Bakanı şimdi ise yeni Cumhurbaşkanı olan Ebul-Hasan Beni Sadr güçlü

de "kanun" gibi telakki ediliyordu. Yine, Rejimin oturduğu, Devrim Konseyi'nin ve Geçici Kabine’nin kaldırıldığı sonraki dönemde Cumhurbaşkanı olan Abul Hasan Beni Sadr ülkenin tamamen izole edilmesine karşı çıkıyordu. Pragmatik bir yaklaşımla Beni Sadr ve siyasi yandaşları, yeni rejimin meşruiyetini tanıyan devletlerle "uygun" ilişkiler geliştirilmesinde israr ediyordu, hatta temel eğilimi batıya dönüktü. Ancak İslamcı güçlerin iktidarlarını pekiştirmeleri sürecinde Beni Sadr 1981 Haziran’ında görevinden azledildi ve daha sonra ülke dışına kaçtı. Böylece İslamcı güçler İran'da iktidarlarını pekiştirmiş oldular. Bkz. Bayram Sinkaya, "Devrimden Günümüze İran Dış Politikasının Dönüşümü,” Mülkiyeliler Birliği Dergisi, cilt 247, sayı 5-6 (Nisan ve Mayis 2005).

8 İran'daki İngiliz petrol tesislerinin millileștiren ve Başbakanlığı sırasında (19511953) Şah Muhammed Pehlevi'yle büyük bir iktidar çekişmesi içine giren İranlı siyasi önder. 1951 yılında İran Başbakanlığına geldi ve 1953 yılında darbe ile görevden uzaklaştırıldı. 
bir şekilde Mussadık politikalarıyla uyumlu milli ve bağımsız politikalar çerçevesinde hareket etmiştir. Beni Sadr ve sonraki yöneticiler selefleri Mussadık, Bezirgân, Sancabi gibi yansızlık (ne Batı ne de Doğu sadece İslam ve İran) sloganı etrafında kalmayı tercih etmişlerdir. Her ne kadar Beni Sadr, Humeyni destekli öğrencilerden rehinelerin kontrolünü almak, BM Araştırma Komisyonuna bilgi vermek istemişse de zaman zaman Humeyni öğrencileri yönlendirerek bu girişimleri engellemiş, bu Komisyon yerine Meclisin rehinelerin durumu ile ilgili sorgulama yapmasını istemiştir.

Bir diğer mesele ise devrimin ihracıdır. Devrimcilere göre devrim, Şiilikten ziyade İslam’ın evrensel mesajları etrafında gerçekleşmeliydi. Önemli olan herkesin "Müslüman kimliğinde birleşmesi ve zulme karşı birlikte hareket etme iradesini ortaya koymasıydı (Gündoğan 2011: 98). $\mathrm{Bu}$ konuda birçok araştırmacıya göre devrim sonrası "rejim ihracının" dini bir görevmiş gibi gündeme getirilmiş olmasına rağmen, asıl amaç, İslam Devriminin korunmasıdır ve dış politikadaki dini söylem bir amaçtan ziyade bir araç olarak kullanılmıştır/kullanılmaktadır (Mehmet 2008: 7-17; Gündoğan 2011: 93-99; Onat 2013: 223-256). İran'ın Devrimle birlikte bölge ülkeleriyle gerginleșen ilişkilerinde olumlu anlamda somut bir gelişme olmamakla birlikte bu konuda Humeyni sonrasında Rafsancani ve Hatemi döneminde ciddi adımlar atılmış, fakat yetersiz olmuştur.

Kısacası, dönemin dışişleri bakan(lar) $1^{9}$ dış politikanın yapımında ve yürütülmesinde etkili olsalar da ancak Humeyni’nin çizdiği sınırlar içinde hareket edebilmişlerdir. Diğer bir ifadeyle, dışişleri bakanlığı görev, yetki ve sorumluluğunu üstlenen adları belirtilen bakanlar Velayet-i Fakih Doktrini ve Humeyni’n talimatlarının dışına çıkmamış, temelde bu talimatların pratiğe aktarılması sürecinde aktif rol oynamışlardır.

9 Şubat 1979 ile Aralık 1981 tarihleri arasında 9 dişişleri bakanı-sırasıyla Ahmed Mirferendereski, Kerim Sancabi, Mehdi Bezirgân, Ibrahim Yazdi, Ebu'l-Hasan Beni Sadr, Sadık Ghotbzadeh, Muhammed Kerim Khodapanahi, Muhammed Ali Rajai, Mir Hüseyin Musavi Hamene- belirli/kısa aralıklarla göreve gelmişlerdir. Aralık 1981 tarihinden sonra ise, Ali Ekber Velayeti tam on alt1 yıl boyunca İran İslam Cumhuriyeti’nin Dışişleri Bakanı olarak görev yaptı. 


\section{3. İran İslam Cumhuriyetinin Ortadoğu'ya Yönelik Politikası: Mısır, Suudi Arabistan, İsrail, Lübnan Hizbullah'ı, Suriye Ve Türkiye}

İran İslam devriminin kalıtsal eğilimleri İran'ın başta körfez ülkelerinde bulunan Arap yöneticileri ve Ortadoğu'nun diğer devletleriyle olan diplomatik ilişkilerinin kırılmasına yol açmıştır. Genel olarak, devrimin iki önemli yönü -dini ve ideolojik- İran'ın Ortadoğu’ya yönelik genişletilmiş bir politika üretmesini ortaya çıkarmıştır. Bir taraftan, İran, ulusal-sosyalist Irak yönetimi ve diğer taraftan Suudi Arabistan gibi kraliyet yönetimi ile var olan problemi bu dönemde doruğa yükselmiştir. Devrim fikirlerinin yayılımı Arap Kraliyet yöneticilerini düşürmeyi amaçlamış ve İran-Irak savaşının ortaya çıkmasında etkili olmuştur. Denilebilir ki, İslam devrimi çoğu Arap Milletlerinin İslami tavırlarını güçlendirmiş, harekete geçirmiştir. Devrimsel düşüncelerin dini ve ideolojik açıdan hız kazanırken başta Humeyni'nin hemen hemen tüm konuşmaları ve ulema sınıfının tavrı Mısır Devlet Başkanı Enver Sedat'ı İslam'a karşı hain olarak görmüşler ve Kamp David Konferansı'na katılımını şiddetle kınamışlardır. Hatta Enver Sedat, İsrail ile Barış Anlaşmalarını yürüttüğü sırada radikal İslam grupları tarafından suikasta uğramış, İran ise bunu desteklemekle kalmayıp başkent Tahran'daki sokaklardan birinin adını suikastı planlayan kişinin adı "Halit El-İslamboli” olarak değiştirmiştir (Jafary 2004: 73).

$\mathrm{Bu}$ olaydan sonra, İran ve Misır’n uzun yıllar sürecek ilişkileri koptu. İki ülke arasındaki ilişkiler karşılıklı olarak elçiliklerini geri çekmeleriyle iyice bozulmuştur. Başkan Sedat'ın Kamp David Anlaşma uzlaşmaları ve Kudüs'e seyahati devrimsel düşüncelerle ters düşmüş, dolayısıyla, Kahire ve Tahran arasındaki diplomatik ilişkiler bir daha düzelemeyecek şekilde bozulmuştur. Öte yandan, İslam devriminin resmi dış politika ideolojisinin hem anti-Siyonizm hem de anti-Amerikan olması Sedat'ın Mısır ile olumlu ilişkiler geliştirmesini engellemiştir. Buna karşılık, Enver Sedat İslam devrimi ve Humeyni karşıtı propagandalar yürütmüştür. Sedat, İslami Cumhuriyet tarafından desteklenen bazı radikal gruplara karşı harekete geçmiş; ancak, Humeyni 
onlarla olan ilişkisini reddetmiştir. Kamp David Anlaşması ardından Humeyni, hem devrik Şah'a yardım ettikleri gerekçesiyle Mısır ile ilişkileri sınırlı tutmuş hem de tüm İslam’a karşı olan büyük ihanetinden dolayı Mısır ile diplomatik ilişkilerin kesilmesine gönderme yapmıştır (Jafary 2004: 73; Keneş 2013: 146).

“Siyonizm’e ilişkin dual eğilimler” iki ülke arasında yıkıcı bir siyasi faktör olarak iki ülkenin diplomatik tarihinde yer edinmiştir. 1979 Devriminden 1989'a kadar, İran’ın diplomatik ilişkilerinin olmadığ 1 bir başka ülke ise Suudi Arabistan'dır. İranlı yöneticilerin tabiriyle “emperyalistlerin Kâbe'deki bekçisi” Suudi Arabistan’n devrimden hemen sonra İran'a tebrik mesajı göndermesi İran yöneticileri tarafından sıcak karşllanmamıştır. Daha önce belirttiğimiz gibi, İslam Cumhuriyeti Suudi Arabistan'daki Şii akımları desteklemiş ve Humeyni Suudi hanedanlığını Müslümanlara ihanet ile suçlamanın yanında Kâbe'nin yönetimindeki yetersizliğini de suçlamıştı. Ek olarak, Humeyni Suudi Arabistan’ı İsrail ile uzlaştı̆̆ 1 ve ABD’nin kuklası pozisyonunda olması nedeniyle hedef göstermişti. Humeyni’nin ayrıca Suudileri ABD ile iyi ekonomik ve askeri ilişkiler hasebiyle "Amerikancı İslam” olarak adlandırdığı bilinmektedir. İslam devriminin ardından Suudi Arabistan'da Şiilerin organize ettiği faaliyetler yasak olmasına karşın 27 Kasım (Muharremin 10’una denk gelen Aşure gününde) 1979 tarihinde törenler şeklinde gösteriler düzenlenmiştir. Buradaki ayaklanmacılar sokaklarda/meydanlarda Humeyni’nin posterlerini sloganlar eşliğinde taşıyarak Kraliyet rejiminin devrilmesini amaçlamıştır. Nihai olarak, protestoların olduğu bölge pasifleştirilmiş ve Şii taleplerinde bulunan yüzlerce kişi gözaltına alınmıştır. İran İslam Cumhuriyetine karşı Suudi Arabistan kendisini müdafaa etmiştir.

Suudi yönetimi Irak-İran savaşı sırasında Irak devletine ortalama 50 milyon dolar bağışlamıştır. Suudi Arabistan, İran-Irak savaşında Irak’ın yanında yer alınca anlaşmazlık zirveye ulaştı. İran'ın günde 6 milyon varil petrol ihraç edememesine karşın, savaş sırasında Suudiler kendi petrol satışını arttırarak İran'ın finansal destek bulmasını engellemiştir (Keneş 2013: 146). Suudi yöneticilerin İran teşviklerine karşı en önemli 
reaksiyonu ise 1987'deki Kâbe'deki Hacıların katliamıdır. Aynı yılın temmuz ayında, Kâbe'deki İran Hacılar Suudi rejiminin aleyhine gösteriler yapmıştır. Ayetullah Humeyni teşvikleriyle bu gösterilerin imansız kimselerin İslam devrimini inkâr amacı taşıdığı doğrultusunda olduğunu belirtmiş Müslümanların uyanık olması amaçlanmıştır (Backlash 2001: 248). Velhasıl, bu olaylar sonunda 400 civarında Hacı öldürülmüş ve Suudi-İran arasında petrol ihracı rekabeti derinleşmiş, İran'in Irak'ı Körfez Konseyi ile işbirliği neticesinde petrol ihracı zayıflatılmıştır. Belirtilmesi gereken önemli bir husus, İran'ın bölgedeki etkisinin İslami hareketlerin aktifleşmesi ile değil, memnun edilmemiş bölge insanları için yeni bir akım oluşturma ve dinamizm etmesiyle mümkün olmuştur.

Lübnan'daki Hizbullah ve Filistin'deki Hamas grupları Sünni-Şii ayrımına bakılmaksızın Tahran tarafından desteklenmiştir. Örneğin, İslam Cumhuriyetinin Hamas'ı desteklemesinin nedeni İslami hareketler ile uyumlu ve İran’ın bölgedeki çıkarlarına aykırı görülmemesi olarak görülebilir. İran’a daha çok yakın Hizbullah ise 1980'lerin başından beri gerek Lübnan'da gerekse de bölgede İslam devriminin askeri gücünün yayılmasına ön ayak olmuş, Ayetullah Humeyni de baskıcı rejimlere karşı bir devrimci sembolü olarak görmüştür. Hizbullah ile İslam Cumhuriyetinin ortak özelliklerinden biri Velayet-i Fakihtir. Hizbullah'ın teorik ve pratik olarak Velayet-i Fakihe bağlılığı aynı zamanda Ayetullah Humeyni ile bütünleşmesini ve onun otoritesine girmesini sağlamıştır.

Hizbullah yetkililerine göre, İslami devrimin yayılması İran'ın bölgede egemen olması anlamına gelmemektedir; ancak, İslam’ın buradaki halklar üzerinde hâkim olabilmesi için İslami yaşamın ve kuralların canlanması ön koşuldur (Aghajani 2008). Hizbullah liderlerinin çoğu da politik kararlar açısından sadece Fakihe güvendiklerini, Ayetullah Humeyni’nin rehberliğine inandıklarını ve coğrafi sınırlarına kesinlikle inanmadıklarını ifade etmişlerdir. ${ }^{10}$ Kısaca Hizbullah egemen güçlerle

10 Daha fazla bilgi için bkz. The History and Function of Hezbollah in Lebanon and the Role of Islamic Revolutionof Iran, 21 Şubat 2005, http://edalatkhahi.ir/ Erişim 01 Mayıs 2014. 
ilişkilerde üçüncü yol olan İslam’ı seçmiş, her türlü vesayet ve siyasi bağımlılığı reddetmiştir. Hizbullah, İslam Devrimi özelliklerini İslam içerisindeki doktrine, Velayet-i Fakihe göre siyasi ve askeri mücadeleyi monarşi, vesayet, diktatoriyel ve diğer rejimlere karşı propaganda üretmiş, bölgede endişe kaynağı olarak görülmüştür. Öte yandan, İran İslam Cumhuriyetinin özellikle Humeyni döneminde İslami hükümetler kurmak ve Sünni farklılıkları ortadan kaldırarak İslam birliği yönetimi çağrısı Sünniler dünyasında önemli bir olumlu sonuç doğurmamış ve "Şiiliğin yaygınlaştırma siyaseti” olarak görüldüğünden karşı koyularak pasifize edilmeye çalışılmıştır.

İran-Suriye ilişkilerine bakacak olursak, Suriye, devrim sonrası İran'da kurulan İslam Cumhuriyetini Arap Dünyasında ilk tanıyan ve İran-Irak savaşında İran'a destek veren ilk ülkedir. Mısır'ın İsrail ile Barış Anlaşmasına gitmesi, Irak ile ilişkilerin siyasi ve ekonomik krizlere gelmesi sonucunda İsrail karşısında İran ile aynı safta yer aldığını söylemek yanlış olmayacaktır (Sinkaya 2011: 39). Öte yandan, İran İslam Devrimini gerçekleştiğinde Suriyeli muhalif Müslüman Kardeşler, Baas rejimini devirip İslami bir rejim kurmaları konusunda İran İslam Yönetiminin kendilerine yardımcı olacağını ümit etmişlerdi (Keneş 2013: 143). Ancak, İran-Irak savaşı böyle bir yardımı zora sokmuş ve dış politikasında bazı ikilemler doğurmuştur: ya Suriye mevcut hükümeti ile işbirliğine gidecekti ya da Suriye'de bir İslam Devleti kurulması için Müslüman Kardeşleri destekleyecekti. Neticede, İran Mevcut Suriye yönetimini tercih etmiştir.

Devrim sonrası sürekli çevresine rejim ihraç etmeyi çabalayan İran'ın devlet-dışı örgütlere verdiği destek tüm ülkelerden ziyada bilhassa Türkiye’yi ilgilendirmiştir. Bu dönemde, her ne kadar Türkiye, Irak-İran Savaşında tarafsızlık politikasını sürdürmüş, ilk yıllarda İran’a ekonomik ambargoya katılmamış ve PKK faaliyetlerini engelleme hususunda İran İslam Cumhuriyeti ile işbirliğine gitmişse de 12 Eylül darbesi İran'da Amerikan yanlısı bir darbe olarak nitelendirilmiştir (Çetirge 1997; Semiz \& Akgün 2005; Eralp \& Tür 1999). İran’n Türkiye'yi Batının laik devlet taklidi-Batının kuyruğu- olarak görmesi ve sömürgeci Batının 
bölgedeki gelişmemiş Müslüman ülkeleri üzerinden sorumlu tutması ikili ilişkilere çoğu zaman olumsuz yansımıştır. Bu nedenle, bu dönem siyasi ve ticari ilişkiler önemli bir ölçüde gerilemiş, hatta ciddi siyasi krizlere neden olmuştur.

\section{4. İran ve ABD: Dostluktan Düşmanlığa}

Soğuk savaş sırasında, başta ABD olmak üzere Büyük Britanya, Sovyetler Birliği gibi Küresel güçler İran’a önemli bir gözle bakmıştır. Bu ilginin ana kaynağı petrol ve petrol rezervlerinin varlığı küresel güçlerin İran'ın iç işlerine, milli meselelerine müdahale etmelerine neden olmuştur. Böylece, İran çekişmelerin toprağ 1 ve güçlenen her ülkenin petrol kaynaklarına hükmetme alanı olmuştur. Buna ek olarak, İran’ın jeopolitik yapısı küresel güçler için bir başka ilgi nedeni haline gelmiştir. Jeopolitik olarak, İran Amerikan’n Ortadoğu'daki kavgasının kalbinde, Sovyetler Birliğinin ise sınır bölgelerinde yer almaktadır. Bu nedenle, Komünizm korkusunun ve tesirinin önlenmesi amaciyla ABD İran ile genelde yakın ilişkiler geliştirmiş, İran üzerinden bölgenin diğer ülkeleri olan Irak, Mısır ve Suriye'ye ulaşmaya çalışmış ve Sovyetler Birliğinden güç alabilecek bölge ülkelerini engelleme yoluna gitmiştir. ABD kendisinin ve en önemli müttefiki olan İsrail'in stratejik çıkarlarının zarara girmemesi için İran ile sıcak temasta olmuştur. Bu amaçla Nixon Yönetimi "çift sütun" veya "twin pillars" denilen stratejiyi birden fazla ülkeyle hem körfezde hem de bölgede uygulamaya koymuştur.

Büyük Britanya’nın Ortadoğu'dan ayrılmasının ardından tüm körfez ülkeleri güçlerini yitirmiş ve yeni istikrarsız ülkeler; Yemen, Umman, Bahreyn, Katar, Birleşik Arap Emirlikleri Komünizm ve Nassirizm tarafından devrilme endişesi taşımışlar. Öte yandan ise yeni gelişmekte olan komşu ülkeler tarafından tehdit altına alınmışlardır. Örneğin, Irak’in yeni gelişen Kuveyt'i kendisinin bir kenti olduğu iddiaları ve Bahreyn'in kendisine ait olduğu politikaları bunu doğrulamaktadır. Elbette, gelişen bu olaylar çift kutuplu dünyanın güçlü iki ülkesinden biri olan ABD’yi daha çok endişeye sevk etmiştir. Bununla beraber, ABD'nin fark ettiği husus eğer ordusu Ortadoğu bölgesine girerse, Araplar bundan hoşnut 
olmayacak ve Sovyetler Birliğine dayalı pan-Arabizm daha çok güçlenecekti. Amerikan ordusunun bölgede varlık göstermesi aynı zamanda Sovyetler Birliğinin ordusunu bölgeye girmesine teşvik edecek ve iki süper güç arasında çok tehlikeli yakınlaşmalar olabilirdi. Dönemin ABD Başkanı Richard Nixon (1969-1974) ve onun Ulusal Güvenlik Danışmanı Hennry Kissinger bölgeye özgü güçleri devreye koyup bölgenin istikrarı ve güvenliğini ulusal çıarlarının aleyhine sonuçlandırmaya karar verdiler (Kenneth 2004: 101).

$\mathrm{Bu}$ nedenle, Komünizmden nefret eden ve ABD ile nikâhlamaya çalışan İran Şahını seçmişlerdi (Kenneth 2004: 101). ABD’nin İran'ı onaylamasıyla İran’ın bir Arap ülkesi olmadığı ve Arapların bundan hoşnut kalmayacağı düşüncesiyle Suudi Arabistan ikinci sütun olarak seçilmişti ki bu İran ile kıyaslanamayacak derece değildi. Şah'ın ABD’nin bölgedeki en önemli dostlarından biri olmasıyla birlikte, petrol fiyatları artmış, Şah silah alımı yaparak güçlenme yoluna gitmiş, "bölgenin jandarması" olarak nitelenmiş, Şah tahtını korumaya çalışmış, Sovyetler Birliğine Karşı bir denge unsuru olarak bakılmış ve diğer birçok gelişmeye ABD yardımıyla İran ön plana çıkmıştır. 1970'lerde Şah hem İran'da hem de bölgede beklenilenden daha fazla güçlenmiş, kendisini Arapların en büyük destekçisi olduğuna ve bölgenin güvenlik ve istikrar konularında belirleyici olduğuna inanmıştır (Kenneth 2004: 103104). Örneğin, 1973'de Tahran askerîlerini Umman'daki Hükümete karşı olan isyanları bastırmak için göndermiştir. Aynı yıl, İran Pakistan'ın diktatoriyel hükümetine destek vermiş ve Somali'ye askerlerini göndererek Etiyopyalılara Sovyetler Birliğinden verilen destek gücünü kırmak istemiştir.

İslam Devrimi İran’ın bölgedeki konumunu çok ciddi bir anlamda değiştirmiştir. İslam devriminin zaferiyle Humeyni ve yeni yönetim daha önceki yönetimin karar ve antlaşmalarını hükümsüz kılmıştır. $\mathrm{Bu}$ hem ulusal hem uluslararası siyasette soğuk savaş şartlarında başta Amerika olmak üzere diplomatik ilişkilerin bitirmesini doğurmuştur. İran'da Devrim sonrası “Büyük Şeytan” ABD ve Batı’ya karşı anti-emperyalist bir söylem hâkimdir. Devrim boyunca, Humeyni ve devrimin 
diğer önderleri, hem ABD’yi hem de SSCB'yi uluslararası politikada kötü niyetli olmakla suçlamışlardır. Washington ve Tahran arasındaki ilişkiler Humeyni tarafından desteklenen üniversite öğrenci gruplarının ABD Elçiliğini işgali ile iyice kötüleşmiştir. Ayetullah Humeyni, çok net bir şekilde anti-Amerikan pozisyonunu İslam devriminden sonra da sürdürmüştür. $A B D$ ve diğer küresel güçlere karşı direniş sadece Humeyni'nin slogan haline getirdiği uluslararası Siyonizm ve sömürgeci söylemlerle değil, uygulamalarıyla (rehine krizi) da farklı şartlarda yerine getirebilmiştir. Time Magazine (07 Ocak 1980) ile yaptığ röportaj bunu açıklayan en iyi örneklerden biridir. Muhabir, Humeyni'ye kendi konumunda herhangi bir kuşkusu olup olmadığını sorunca, Humeyni şöyle cevaplamıştır: "Şuna inanıyoruz ki süper güçler de iman gücüyle mağlup edilebilir. ABD’nin güçlü yönetimine karşı koyuyoruz. Biliyoruz ki $A B D$ iyi durumda, fakat biz itibarımızı ve asaletimizi her zaman savunacağız. ABD’nin üstesinden gelmeliyiz. Eşitsizliği ve sömürüyü kabullenemeyiz, ezilen ve mazlum olarak görülmek istemiyoruz. ABD bizi yenebilir, ancak devrimimizi asla alt edemeyecektir. Eminim ki biz bu devrimi kazanacağız".

Öte yandan, Washington'un İran'a yönelik "bölgenin jandarması” politikası İslam Devrimi ile beraber son bulmuştur. Hevesli Irak’a verilen bu bölgesel pozisyon ayrıca daha önce Sovyet Birliğine yaslanan Irak'ın Batı Bloğundan silah satın alma ve İran'ın bölgeye fundamentalist devrim ihracına karşı ABD destekli bir yük denge olarak görülmüştür. ABD, İran'ın ekonomik ve askeri gücünü kırma, ithalat-ihracatını engelleme, İslam devriminin korkusunu önleme girişimlerine karşı Saddam Rejimine tam olarak destek vermiştir. Körfez bölgesine saldırı demek ABD’nin hayati önem taşıyan çıkarlarına karşı egemenlik kurulduğu anlamına gelmekteydi. 1980’lerde Reagan Yönetimi döneminde, bölge ülkelerinin İran’ın siyasi teşvikleri ve anti-Amerikan radikal gruplarının oluşumuna destek vermesi Washington'un Ortadoğu çıkarlarına büyük darbe vurmuştur. Binaenaleyh, güvenlik konusunda Reagan ve Gorbaçov yönetimlerinin ekonomik ve siyasi meşruluğuna yönelik yeni düşünceler ortaya atılmışsa da geleneksel olan realist teorinin yanlış anlamaları neticesinde kolektif güvenlik sistemi kurmuştur. 
Ancak, güçler dengesi körfez bölgesinde istikrar sağlamamış; aksine, İran güvenlik sistemi içerisinde yer almamış ve sistemin içerinde yer alan diğer bölgesel güçlere karşı da hareket etmiştir.

\section{Sonuç}

1979 İslam devriminden ardından İran, iç politik sisteminde olduğu gibi dış politikada da köklü değişiklikler yaşamıştır. Daha önce de belirtildiği gibi, kendine has (sui generis) olarak tarif edilebilecek İran Dış Politikası iç siyasetteki nevi şahsına münhasır aidiyetlerden kaynaklanmaktadır. Bu nedenle, İran’ın izlediği dış politika yönelimleri ülke içerisindeki Şiiliğin protest yapısından bağımsız olduğunu düşünemeyiz. İslam Cumhuriyeti bir ideolojik devrimin ürünü olmakla beraber temeli İslam’ın Şii mezhebine ve ulemanın yorumuna dayanmaktadır. $\mathrm{Bu}$ devrimin tesiri yalnız İran’ın içinde değil, dış işlerinde de belirleyici olmuştur.

İslam Devrimi Amerikan kapitalizmi ve Batı Avrupa'daki müttefik düşünceleri ile Sovyetler Birliği Komünizmi ve Doğu Avrupa müttefikleri düşünceleri arasında yeni bir ideoloji-üçüncü yol ortaya koymuştur. Böylece İran İslam Cumhuriyetỉnin Dış Politikasını belirleyen en önemli etken devrim ideolojisi olmuştur. Humeyni yönetimindeki İran İslam Devrimi özellikle Ortadoğu'daki üçüncü dünya ülkelerin imdadına yetişmek, sıkıştırılmış Batı ve Doğu hegemonyasındaki bu ülkeleri kurtararak devrimi bu ülkelere ihraç etmek ve devrimi İran Dış Politikasında bir söylem, bir kurumsal retorik işlevi üstlenmiştir.

Bilinmesi gereken bir başka husus, İran siyasi işleyişinin son ve en büyük karar vereni, Rehber Humeyni ne saf idealist ne de saf bir realist politika için çabalamıştır. İran'ın siyasi grupların pozisyonunu göz önüne aldığımız zaman, Humeyni ve devrim liderleri genel olarak milli menfaatleri ve dış politikaya ilişkin üçüncü dünyanın liderliğine soyunan ve yeni bir "model" öneren anti-emperyalist bir söylem benimsemişlerdir. Önce İran’ Uluslararası düzende izole etmeye çalışmış daha sonra bu izolasyonu dini bir lider olarak kendine mal ederek uygun şartlarda ve İslami prensiplerle meydan okuyarak kırmaya çalışmıştır. Tüm 
bu siyasi faaliyetlerin amacı Velayet-i Fakih rehberliğinde, İslam Cumhuriyeti çerçevesinde İran'ın bağımsızlığını garanti etmektir. Bununla beraber, İslam Devriminin yayılımı-ihracı zamanla değişme göstermektedir. Realistler ve idealistler bu hususta İslam Devriminin güçlenmesiistihkâm güçlendirme- taraftarları olarak direnmişlerdir.

Ayetullah Muntazeri de Humeyni'nin geleneksel devrim ihracı politikalarına benzer olarak İslam Devriminin zaferine diğer Müslüman ülkeler gözünden baskıcı ve otoriter rejimlere karşı ezilenlerin, mazlumların, safında gerçekleşebileceğine inanmıştır. Devrim ihracına maruz kalmadan da bölgedeki ve dünyadaki İslam tarafından örnek alınabileceğini önermiştir. İslam Devrimi çok büyük bir genişleme-yayılma yapamamasına rağmen İran İslam Cumhuriyetinin mevcudiyetini ve sürdürebilirliğini bölgedeki diğer despot ve anti-demokratik olan hükümetlere karşı liberal/özgürlükçü hareketlere ideolojik bir ilham vermiş, süper güçlerin dost/müttefik yönetimlerini de ciddi anlamda tehdit etmiştir. Humeyni’n vefatından sonra, Şura-ı Hibregan tarafından Ayetullah Ali Hamaney Fakih atandıktan sonra her ne kadar Fakih'in yetkileri artırılmışsa da, Velayet-i Fakih kurumu artık, Humeyni dönemindeki dini ve siyasi otoritenin merkezinden yavaş yavaş çıktığı söylenebilir (Milani 2004: 191). Her ne kadar Hamaney İran'daki eğilimi Humeyni dönemindeki ile aynı olduğunu ifade etse de Velayet-i Fakih'in artık İslam Cumhuriyetinin dini otoritesinin başlıca kaynağ 1 ve güçlü siyasi organı olmadığı görülmektedir.

1989 yılında Haşimi Rafsancani Humeyni’n ölümü üzerine Cumhurbaşkanı seçildi. İran’’n Dış Politikası Humeyni dönemindekinden farklı olarak pragmatizme doğru kaydığı ve normalleşme/rasyonel dış siyaset arayışları olduğu söylenelebilir. Çeşitli faktörler buna neden olsa da yıllarca süren Irak-İran Savaşı ve Soğuk Savaşının bitimi ana faktörlerdir. Özetleyecek olursak, dünyanın en eski monarşilerinden birinin yıkılmasının ardından Humeyni yönetimindeki (1979-1989) yeni düzen siyasi ve dini açıdan iki dış politika prensibi muhafaza etmiştir: "Ne Batı ne Doğu, sadece İslam" ve "rejim ihracı". Günümüzde de bu söylem ve teorik dış politika prensipleri olarak hala varlığını korumaktadır. 


\section{Kaynakça}

Aghajani, Ali (2008): "An Analysis about the Reflection of Islamic Revolution in Lebanon”, Pegah Magazine, No: 220.

Backlash, Shaul (2001): “Iran's Foreign Policy under Islamic Republic, 1979-2000",(der. Carl Brown) Diplomacy in the Middle East, I.B. Tauris, New York.

Çetirge, A. Yurdanur (1997): Namludaki Karanfilden Şeraite-İran, Bilgi Yayınları, Ankara.

Efegil, Ertan(2012): “İran’ın Dış Politika Yapım Sürecini Etkileyen Unsurlar”, Ortadoğu Analiz, Cilt 4, Sayı 48, Aralık 2012.

Eralp, Atilla \& Tür, Özlem (1999): “İran'la Devrim Sonrası İlişkiler”, (der) Meliha B. AltunIşık, Türkiye ve Ortadoğu; Tarih, Kimlik ve Güvenlik, Boyut Yayınları, İstanbul.

Gündoğan, Ünal(2011): “Geçmişten Bugüne İran İslam Devrimi: Genel Değerlendirme”, Ortadoğu Analiz, Cilt 3, Sayı 29, Mayıs 2011.

Hatemi, Hüseyin(çev.) (1980): İran İslam Cumhuriyeti Anayasası, Çağrı Yayınları, İstanbul.

Jafary, Asghar (2004): The Iranian International Relations After the Islamic Revolution, Etelaat Publication, Tehran.

Keneş, Bülent (2013): İran Siyasetinin İç Yüzü, Timaş Yayınları, İstanbul.

Kenneth, Pollack (2004): The Persian Puzzle: The Conflict Between America and Iran, Random House, New York.

Keskin, Arif (2008): “Şii Jeopolitiği ve İran”, (ed) Mehmet Tuncel, Ortadoğu’da Güç Savaşları: Hedef Neden İran?, Etkileşim Yayınları, İstanbul

"Man of the Year: Interview With Khomeini", Time Magazine, 07 Ocak 1980, 
http://content.time.com/time/magazine/article/0,9171,923858,00.html Erişim tarihi: 5

Mayıs 2014

Milani, M. Muhsin (2004): “Humeyni' den Hamaney'e Velayet-i Fakih Kurumunun Değişimi”, Dokuz Eylül Üniversitesi İlahiyat Fakültesi Dergisi, Sayı 19.

Onat, Hasan (2013): "İran İslam Devrimi ve Şiilik", e-makâlât Mezhep Araştırmaları, VI/2, Güz 2013.

Rakel, E. Patricia (2007): "Iranian foreign policy since the Iranian Islamic Revolution: 1979-2006", Perspectives on Global Development and Technology, Cilt 6 Sayı 1.

Semiz, Yaşar \& Akgün, Birol (2005): "Büyük Ortadoğu Jeopolitiğinde İran-ABD İlişkileri”, Sosyal ve Ekonomik Araştırmalar Dergisi, Cilt 5, Sayı 9.

Sinkaya, Bayram (2005): "Devrimden Günümüze İran D1ş Politikasının Dönüşümü,” Mülkiyeliler Birliği Dergisi, Cilt 247, Sayı 5-6, Nisan ve Mayıs 2005.

Sinkaya, Bayram (2011): "İran-Suriye İlişkileri ve Suriye Halk İsyanı", Ortadoğu Analiz, Cilt, 3, Sayı, 33.

Şahin, Mehmet (2008): "İan Dış Politikasının Dini Retoriğì”, Akademik Orta Doğu, Cilt 2, Sayı 2.

Üstün, S. İsmail (1999): Humeyni'den Hamaney'e İran İslam Cumhuriyeti Yönetim Biçimi, Birleşik Yayınları, İstanbul. 
Abstract: -Iran Foreign Policy in Khomeini Period (1979-1989)-: The main purpose of this article is to investigate the February 1979 revolution as a result of the Velayat-e Faqih theory (Guardianship of the Islamic Jurists) reflection on foreign policy in the period of the Islamic Republic of Iran leading up to the death of Khomeini. To study Iran Foreign Policy, it requires knowing the relationship of religious institutions, doctrines, and characteristics and structure of Shia protests rather than political/international relations theories. In this study, in order to fully understand Iran Foreign Policy, we need to address beyond Eurocentric-traditional- international relations theories (Realism, Liberalism, Marxism, Constructivism and so on). At first, it discusses the factors that influence Iran Foreign Policy and impact of revolution and leaders on foreign policy and explains different aspects and achievements as well. And then, Islamic Republic of Iran Policies towards Middle Eastern States and the United States are discussed.

Key words: Iran, Foreign Policy, Guardianship of the Islamic Jurists (Velayat-e Faqih), Middle East, Revolution, Khomeini. 